\title{
Esiste l'identità repubblicana? Conferenza
}

\section{Ernesto Galli della Loggia}

Storicamente, 2 (2006).

ISSN: 1825-411X. Art. no. 64. DOI: 10.12977/stor536

13 aprile 2006

Prof. Ernesto Galli della Loggia

(Università degli Studi di Milano)

Esiste l'identità repubblicana?

(conferenza)

[[figure]]figures/2006/Galli-Loggia_1/Galli-Loggia_1_2006_01.jpg[[/figure]] 